\title{
Epidemiological Clinical and Profile of Cranio-spinal Dysraphisms in Madagascar
}

\author{
Bemora Joseph Synèse, Andrianaivo Radotina Tony, Masina Ndalana d'Assise, \\ Ratovondrainy Willy, Rabararijaona Mamiarisoa, and Andriamamonjy Clément
}

\section{ABSTRACT}

Cranio-spinal dysraphisms are a set of congenital malformations resulting from a defect in closing the neural tube during embryonic development. The objective of this study was to describe the epidemiological-clinical profile of these malformations in Madagascar. It was a retrospective, descriptive study and metacentric from January 01, 2016 to December 31, 2018; all cases of cranio-spinal dysraphisms seen in two neurosurgery centers in Madagascar. We have collected 32 cases of cranio-spinal dysraphisms. The hospital prevalence was $0.37 \%$. Among these children, the mean age was 8.48 months with an extreme of 1 day to 6 years; there was a feminine predominance $(53,12 \%)$, with a sex ratio of 0.88 . The absence of maternal intake of folic acid, the intake of folic acid outside the recommended periods, the birth order of the children and maternal pathologies during pregnancy were found as etiology. Cranial topography predominated in $56.25 \%$ (18 cases) and $68.75 \%$ of the children were asymptomatic. An association with hydrocephalus was found in $31.25 \%$ of cases. Prevention of known risk factors is essential, antenatal diagnosis is important for early management and improved prognosis. The treatment is surgical.

Keywords: Etiology, surgery, Neural Tube Defects, Hydrocephalus.
Published Online: December 15, 2020

ISSN: $2593-8339$

DOI: $10.24018 /$ ejmed.2020.2.6.606

Bemora Joseph Synèse *

Department of Neurosurgery, CHU-JRA,

Antananarivo, Madagascar.

(e-mail: josbemora@yahoo.fr)

Andrianaivo Radotina Tony

Department of Neurosurgery, CHU-JRA,

Antananarivo, Madagascar.

Masina Ndalana d'Assise

Department of Neurosurgery, CHU-JRA,

Antananarivo, Madagascar.

Ratovondrainy Willy

Department of Neurosurgery, CENHOSOA, Antananarivo, Madagascar. Rabararijaona Mamiarisoa

Department of Neurosurgery, CHU

Tambohobe Fianarantsoa, Madagascar.

Andriamamonjy Clément

Department of Neurosurgery, CHU-JRA,

Antananarivo, Madagascar.

*Corresponding Author

\section{INTRODUCTION}

The term cranio-spinal dysraphism corresponds to a set of congenital malformations, resulting from a defect of closure of the neural tube of variable extent, during the fourth week of the development of embryonic life. They are usually divided into cephalic and spinal forms [1]. They are caused by an absence of complete or partial closure of the neural tube between the 22nd and 28th day of gestation [2], [3]. Each year, more than 300,000 childrens are born with a neural tube defect, $70 \%$ of which are in developing countries [4]. The prevalence in developed countries has fallen sharply due to prevention through genetic counseling; the periconceptional intake of folic acid, one of the main predisposing factors found, although its role in the development of cranio-spinal dysraphisms is unknown [5] and the precision of the antenatal diagnosis with legalization of therapeutic abortion [6]. These malformations usually cause significant psychomotor and sphincteric sequelae requiring multidisciplinary management [6]. The objective of this study was to define the epidemiological-clinical profile of these malformations in Madagascar in order to improve their management.

\section{MethodOLOGY}

We conducted a retrospective, descriptive and multicenter study of children hospitalized and cared for in the Neurosurgery department of the Joseph Ravoahangy Andrianavalona University Hospital Center (CHU-JRA) as well as the Pediatrics department of the Soavinandriana Hospital Center (CENHOSOA) of the 1st January 2016 to December 31, 2018. All children with either cranial and / or spinal dysraphism, with a complete file were studied (clinical information and antecedents well detailed).

The parameters studied were epidemiological data (frequency, prevalence, age, gender, geographical origin and history) and clinical data (discovery of the malformation, topography, appearance of the skin coating, associated malformations and clinical signs). The data that was collected was entered on Microsoft Excel 2019® and analyzed on $\mathrm{R} \AA$ software version 3.5.2 with an IDE (Integrated Development Environment) RStudio ${ }^{\circledR}$ version 1.1.456. 


\section{RESULTS}

During the targeted period, 32 cases of cranio-spinal dysraphisms with a complete file were listed in these two departments. In our series, cranio-spinal dysraphisms represented $0.37 \%$ of hospitalizations with a frequency of 10.6 cases per year ( 6 cases / years for cranial locations and 4.66 cases / years for spinal forms). Among these children, there was a slight female predominance $(53.12 \%)$ with a ratio of 0.88 ; the average age was 8.48 months with an extreme of 1 day and 6 years. Depending on the geographical origin, populations living in the highlands had $43.75 \%$ craniospinal dysraphism against $34.37 \%$ those in coastal areas. Only $56.25 \%$ of mothers who had a child with cranio-spinal dysraphism took folic acid during pregnancy. For the birth order of children, it was found that children who were born first are the most affected by the malformation, $43.75 \%$ of cases (Fig. 1).

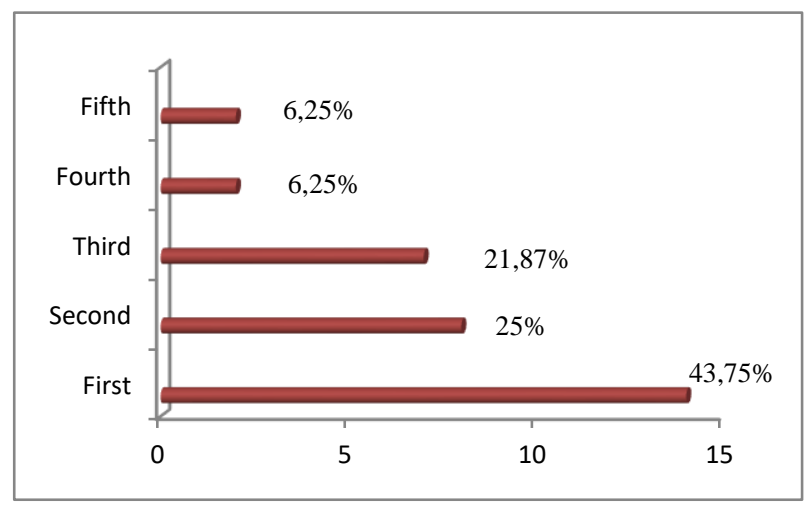

Fig. 1. Distribution of children by birth order.

Clinically, all of these malformations were discovered at birth. According to the topography, 17 cases of dysraphisms were cranial, ie $53.12 \%$ against $46.87 \%$ of spinal topography (15 cases), to note that there were no cases of cranioschisis or rachischisis; and in 8 of the 32 cases, the malformation was ruptured within 48 hours of birth. The location of these various malformations is shown in Table I.

TABLE I: DISTRIBUTION OF CRANIO-SPINAL DYSRAPHISMS ACCORDING TO

\begin{tabular}{cccc}
\multicolumn{4}{c}{ LOCATION } \\
\hline \hline $\begin{array}{c}\text { Type of } \\
\text { malformations }\end{array}$ & Localisation & $\begin{array}{c}\text { Number } \\
(\mathrm{n}=32)\end{array}$ & Percent $(\%)$ \\
\hline & Ethmoid-nasal & 2 & 06,25 \\
Cranial & Frontal & 2 & 06,25 \\
dysraphism & Parietal & 5 & 15,62 \\
(17cases) & Parieto-occipital & 1 & 3,12 \\
& Occipital & 6 & 18,75 \\
& Occipito- & 1 & 3,12 \\
& cervical & 1 & 3,12 \\
& Cervical & 1 & 3,12 \\
& Cervico- & 1 & 06,25 \\
Dysraphisme & thoracic & 2 & 3,12 \\
spinal (15cas) & Thoracic & 1 & 15,62 \\
& Thoraco-lumbar & 5 & 12,50 \\
& Lumbar & 4 & 3,12 \\
\hline \hline & Lumbosacral & 1 &
\end{tabular}

Associated with this malformation, we found hydrocephalus $(31.25 \%)$, an Arnold-Chiari malformation (9.37\%), anal imperforation and clubfoot with a respective rate of $3.12 \%$.
On the evolutionary level, the postoperative complications were dominated by meningitis and SCL leakage with a respective rate of $7.69 \%$ and $3.84 \%$. The average length of hospital stay was 12.43 days with extremes of 1 day and 60 days.

\section{DISCUSSION}

From an epidemiological point of view, the frequency of cranio-spinal dysraphisms varies from country to country. In our study, this frequency was 10.6 cases per year (6 cases / year for cranial locations and 4.66 cases / year for spinal forms), with a prevalence of $0.37 \%$ hospitalization. In Niger, this annual frequency is 14.66 cases [4] for meningoencephaloceles; in Burkina Faso 24.4 cases per year [7] for spinal dysraphisms. The worldwide prevalence of cranio-spinal dysraphisms ranges from 0.3 to 199.4 per 10,000 births. A delay in consultation was observed both in our study and in other African countries [4], [7], in fact the average age at the time of diagnosis was 8.48 months in our study with an extreme of 1 day and 6 years old. This delay could be related to the distance from the neurosurgery centers. According to gender, in our series we noted a slight female predominance found in $53.12 \%$ with a sex ratio of 0.88 , but statistical analysis had shown that the relationship between gender and cranio-spinal dysraphisms was not significant with a p-value of 0.99. This slight female predominance was known in the literature, it would be due to epigenetic phenomena, the loss of a fairly large proportion of male fetuses with cranio-spinal dysraphism at an early gestational age, differences in susceptibility to environmental factors. ,... [8], [9]. In our study, $43.75 \%$ of children hospitalized for cranio-spinal dysraphism come from the former province of Antananarivo and that $34.37 \%$ come from the province and that $21.87 \%$ were not specified in the file. The relationship between geographic origins and cranio-spinal dysraphisms was statistically insignificant in our case (p-value at 0.31), however we observe a slight predominance of children from the highlands with craniospinal dysraphisms compared to other geographic origins. This low rate of children from the provinces has also been reported by some authors [10]-[12], which could be explained by the difficulty of accessing care for children from the province. Maternal folic acid deficiency during the periconceptional period is known to be one of the risk factors for cranio-spinal dysraphism. In our case, $43.75 \%$ of mothers did not take it during pregnancy. Mothers who did not take folic acid had a high prevalence of cranio-spinal dysraphism; in addition, the difference between folic acid intake and cranio-spinal dysraphisms was statistically significant with a p-value $<0.001$.

Our result matches the data in the literature [13]-[16]. This folic acid should be taken between 1 month before conception and throughout the first trimester of pregnancy [17]. There is a correlation between the birth order of children and the existence of craniospinal dysraphisms; indeed, the first child is the most at risk of developing this malformation, this possibility has been seen in our study as well as in the literature [6], [18].

Clinically, the diagnosis of cranio-spinal dysraphism should be made prenatal using ultrasound or fetal MRI [19], 
[20]. It should be noted that ultrasound is a dependent manipulative technique, it takes some experience to be able to visualize this malformation. In our case, no malformation was diagnosed antenatal. The location of this malformation is variable; for the cranial form, the occipital topography is by far the most frequent [4], [6], [11], found in $18.75 \%$ in our series; for spinal forms, the lumbar (15.62\%) and lumbosacral $(12.50 \%)$ localization is the most frequent both in the literature and in our study [6], [7], [10], [21], [23]. For associated malformations, we found $31.25 \%$ hydrocephalus; this malformation is variable in the literature, it can be hydrocephalus, Dandy Walker and other polymalformative syndrome [7], [4], [10], [12], [23], [24].

The course of cranio-spinal dysraphism remains variable, the length of hospitalization depends on the course and the existence of a possible complication. The most frequent complication is an infection such as meningitis (7.69\%) and SCL leakage $(3.84 \%)$, found both in our study and in the literature [4], [6], [10], [12], [22], [23].

\section{CONCLUSION}

Cranio-spinal dysraphisms are among the congenital malformations mainly linked to a deficiency in folic acid. Antenatal diagnosis remains essential, based on the use of ultrasound or a fetal MRI. Faced with this malformation, it is necessary to look for associated malformations, especially hydrocephalus. The course and the prognosis depend on the topography. Complications are frequent; the best management remains prevention by supplementation with folic acid and early surgical treatment of malformations to prevent their rupture.

\section{REFERENCES}

[1] Messaoud A, El Mhabrech H, Zrig A, Yahyaoui S, Ben Salem A, Brahem R, et al. Le tube neural foetal: Du normal au pathologique. Le tube neural foetal du Normal au Pathologique, Paris: 4lème Congrès annuel de la Société Française de NeuroRadiologie; 2014, p1.

[2] Mohammed Omar Z, Omar B. Abdelbasit, Meeralebbae Shaheed M, Abeer Miqdad M, Mohamed Khalil I, Naif Al-Enazy M, et al Epidemiology of neural tube defects in Saudi Arabia. Saudi Med J. 2014; 35(1): S29-35.

[3] Maria L, Santos P, Reyes C, Cortez-escalante JJ. Prevention of neura tube defects by the fortification of flour with folic acid: a populationbased retrospective study in Brazil. Bull World Health Organ. 2016; 94(1): 22-9.

[4] Rabiou Maman S, Habou O, Adamou H, Amadou Magagi I, Magagi A, Maazou H. Caractéristiques épidémiologiques, cliniques et pronostiques des encéphalocèles opérées à l'Hôpital National de Zinder. Annales de l'Université Abdou Moumouni, 2016; 2: 48-54.

[5] Lemay P. Anomalies du tube neural: Mieux comprendre les causes génétiques de cette pathologie complexe [Thèse]. Biochimie et médecine moléculaire: Montréal; 2017. 124p.

[6] Sanoussi S, Gamatie Y, Kelani A, Sbai C, Abarchi H, Bazira L. Malformations du tube neural au Niger: A propos de 387 cas en 10 ans: Plaidoyer pour un traitement préventif par l'acide folique en période périconceptionnelle. Medecine Afrique Noire. 2001; 48(12): 510-5.

[7] Sawadogo I. Spina bifida Aspects épidemiologique, clinique, thérapeutique et pronostic dans le service de neurochirurgie du CHUYO; A propos de 81 cas [Thèse]. Médecine humaine : Ouagadougou ; 2012; 107p.

[8] Poletta FA, Rittler M, Saleme C, Campa H, Gili JA, Pawluk MS, et al. Neural tube defects: Sex ratio changes after fortification with folic acid. PLoS One. 2018; 13(3): 1-12.
[9] Liu J, Xie J, Li Z, Greene NDE, Ren A. Sex differences in the prevalence of neural tube defects and preventive effects of folic acid ( FA) supplementation among five counties in northern China: results from a population-based birth defect surveillance programme. Bm Med J Open. 2018; 8(11): 1-6.

[10] Sidi S. Etude du Spina bifida dans le service de chirurgie pédiatrique CHU GT [Thèse]. Médecine humaine: Bamako; 2008. 104p.

[11] Ech-chahed H. Prise en charge des encéphalocèles: expérience du service de neurochirurgie [Thèse]. Médecine Humaine: Marrakech; 2013. 65p

[12] El-Faouzi M. Les méningo-encéphalocèles [Thèse]. Médecine Humaine: Antananarivo; 2005; 67p.

[13] Kancherla V, Sharif O, Hasan I, Hamid R, Paul L, Selhub J, et al Prenatal folic acid use associated with decreased risk of myelomeningocele: A case- control study offers further support for folic acid fortification in Bangladesh. PLoS One. 2017; 12(11): 1-10.

[14] Dehe S, Vodovar V, Verite V, Goujard J. Prévention primaire des anomalies de fermeture du tube neural par supplémentation périconceptionnelle en acide folique. Bulletin Epidémiologique Hebdomadaire. 2000 Mai; 21: 87-9.

[15] Anne-flore P. Evaluation de la prise d'acide folique par les femmes enceintes onze ans après les recommandations nationales [Thèse] Médecine humaine : Paris 7; 2014. 87p.

[16] Liu J, Li Z, Ye R, Liu J, Ren A. Periconceptional folic acid supplementation and sex difference in prevention of neural tube defects and their subtypes in China: results from a large prospective cohort study. Nutr J. 2018; 17(1): 1-7.

[17] Dessie MA, Zeleke EG, Workie SB, Berihun AW. Folic acid usage and associated factors in the prevention of neural tube defects among pregnant women in Ethiopia: cross- sectional study. BMC Pregnancy Childbirth. 2017; 17(1): 1-8

[18] Elwood JM, Mcbride ML. Contrasting effects of maternal fertility and birth rank on the occurrence of neural tube defects. Epidemiol an Community Heal. 1979; 33(1): 78-83.

[19] Matuszewski L. Diagnostic prénatal des dysraphismes spinaux: corrélation des données aténatales et post-natales [Thèse]. Médecine humaine: Lorraine ; 2016. 44p.

[20] Bodin CR, Rasmussen MM, Tabor A, Westbom L, Tiblad E, Ekelund $\mathrm{CK}$, et al. Ultrasound in Prenatal Diagnostics and Its Impact on the Epidemiology of Spina Bifida in a National Cohort from Denmark with a Comparison to Sweden. Biomed Res Int. 2018; 2018: 8.

[21] Wald NJ, Althouse R. Sex differences in the location of a spina bifida lesion. J Med Genet. 1993; 30(3): 262-3.

[22] Sawadogo I. Spina bifida Aspects épidemiologique, clinique, thérapeutique et pronostic dans le service de neurochirurgie du CHUYO; A propos de 81 cas [Thèse]. Médecine humaine: Ouagadougou 2012; 107p.

[23] Alhenj Haingotatamo H. Les spina bifida diagnostiqués dans le service de neurochirurgie de janvier 1998 au décembre 2006 [Thèse] Médecine humaine: Antananarivo; 2008. 72p

[24] Schoner K, Axt-fliedner R, Bald R, Fritz B, Kohlhase J, Kohl T, et al. Fetal Pathology of Neural Tube Defects - An Overview of 68 Cases. Geburtsh Frauenheilk. 2017; 77(5): 495-507.

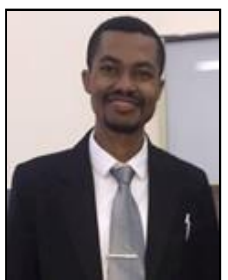

Bemora was born on December 20, 1987 in Maroantsetra, he is the second son of a family of three children. He began his medical studies in 2006 after having obtained the baccalaureate with honors He was admitted to the competitive examination to be a specialist in 2012 and continued his studies in France then became a specialist in Neurosurgery in 2018. He was admitted to the clinical examination in 2019 and currently, he is head of clinic in Neurosurgery at the Faculty of Antananarivo medicine at CHU JRA Madagascar. He has participated in various national and international research and publications. 